\title{
Anne-Baba Tutum Ölçeğinin Türk İşaret Dili'ne Uyarlanması ve Sağır Ebeveynlerin Çocuk Yetiştirme Tutumları*
}

\section{Hasan Hüseyin Saç1 ${ }^{1}$}

\section{Arzu Özyürek²}

Type/Tür:

Research/Araştırma

Received/Geliş Tarihi: August

13/ 13 Ağustos 2020

Accepted/Kabul Tarihi: February

12/ 12 Şubat 2021

Page numbers/Sayfa No: $825-843$

Corresponding

Author/İletişimden Sorumlu

Yazar:a.ozyurek@karabuk.edu.tr

\section{$\checkmark$ iThenticate $^{\circ}$}

This paper was checked for plagiarism using iThenticate during the preview process and before publication. / Bu çalışma ön inceleme sürecinde ve yayımlanmadan önce iThenticate yazılımı ile taranmıştır.

Copyright $@ 2017$ by Cumhuriye University, Faculty of Education. All rights reserved.

\section{Öz}

Çocukların gelişimi ve topluma uyum sağlayabilmesi için, annebabalarının tutumları etkilidir. Anne-babaların çocuk yetiştirmeye yönelik tutumları kendi kişisel özellikleri, çocuğa ait özellikler ve diğer pek çok faktörden etkilenebilmektedir. Engelli veya normal gelişimsel özelliklere sahip bireylerden oluşan tüm ailelerde, annebabalık her ebeveynin sorumluğudur. Sağır toplumu, gündelik iletişimde Türk İşaret Dilini (TID) kullanan bireylerden oluşan topluluk olarak adlandırılmaktadır. Betimsel tarama modelindeki bu araştırmanın amacı, 5-6 yaşında çocuğu bulunan sağır ebeveynlerin çocuk yetiştirme tutumlarını incelemek amacıyla bir ölçek uyarlaması yapmaktır. Araştırmanın çalışma grubunu hedef yaş grubunda çocuğu bulunan ve Türk İşaret Dili'ni iletişim dili olarak kullanan 258 sağır ebeveyn oluşturmuştur. Veri toplamada Anne-Baba Tutum Ölçeği (ABTÖ)-A Formu kullanılmıştır. Ölçek Türk İşaret Diline (TID) çevrilmiş ve Doğrulayıcı Faktör Analizi (DFA) yapılmıştır. Cronbach Alfa Güvenirlik Katsayıları Demokratik Tutum alt boyutu için .0,91, Baskıcı ve Otoriter Tutum için 0,86, Aşırı Hoşgörülü Tutum için 0,89 bulunmuştur. ABTÖ-A Formu 38 maddelik TỉD Versiyonunun sağır kültürüne ve Türk İşaret Diline uygun olduğu, sağır ebeveynlerin çocuk yetiştirme tutumlarını belirlemede kullanılabileceği belirlenmiştir. Çalışmada sağır annelerin Aşırı Hoşgörülü Tutum alt boyut puanının babalara göre, 26-30 yaşındaki ebeveynlerin Baskıcı ve Otoriter Tutum alt boyut puanlarının 36-40 yaşındakilere göre daha yüksek olduğu saptanmıştır.

Anahtar Kelimeler: Türk İşaret Dili, sağır ebeveynler, çocuk yetiştirme tutumları, ölçek uyarlama, okul öncesi dönemi.

\section{Suggested APA Citation/Önerilen APA Atıf Biçimi:}

Saçı, H.H., \& Özyürek, A. (2021). Anne-baba tutum ölçeğinin Türk İşaret Dili'ne uyarlanması ve sağır ebeveynlerin çocuk yetiştirme tutumları. Cumhuriyet International Journal of Education, 10(2), 825843. http://dx.doi.org/10.30703/cije.779975

\footnotetext{
*Bu çalışma, Karabük Üniversitesinde, 2019 yılında, ikinci yazarın danışmanlığında tamamlanan birinci yazarın yüksek lisans tezinin bir bölümünden oluşturulmuştur.

1 Öğretmen, Kastamonu Rehberlik ve Araştırma Merkezi, Kastamonu/Türkiye Teacher, Kastamonu Guidance and Research Center, Kastamonu/Turkey e-mail: hhsaci@gmail.com ORCID ID: orcid.org/0000-0002-2015-5128

2 Prof. Dr., Karabük Üniversitesi, Sağlık Bilimleri Fakültesi, Çocuk Gelişimi Bölümü, Karabük/Türkiye Prof. Dr., Karabuk University, Faculty of Health Sciences, Department of Child Development, Karabuk/Turkey e-mail: a.ozyurek@karabuk.edu.tr ORCID ID: orcid.org/0000-0002-3083-7202
} 


\title{
Adaptation of Parental Attitude Scale into Turkish Sign Language and Child Rearing Attitudes of Deaf Parents
}

\begin{abstract}
Parents' attitudes are effective for children's development and adaptation to society. Parents' attitudes towards child rearing can be affected by their personal characteristics, characteristics of the child and many other factors. In all families consisting of individuals with disabilities or normal developmental characteristics, parenting is the responsibility of each parent. Deaf community is called as the community consisting of individuals who use Turkish Sign Language (TSL) in daily communication. The aim of this study designed as description screening model is to make a scale adaptation in order to examine child rearing attitudes of deaf parents who have children at the age of 5-6. The study group of the study consists of 258 deaf parents with children in the target age group who use Turkish Sign Language as the communication language. In order to collect the data, the Parent Attitude Scale (PAS)-A form was used. The scale was translated into Turkish Sign Language (TSL) and Confirmatory Factor Analysis (CFA) was performed. Cronbach alpha was calculated to determine the reliability of the scale (Democratik Attitude .91, Repressive and Authoritarian Attitude .86, Overly Tolerant Attitude .89). It was concluded that the PAS-A Version of the TSL Version (38 items) was compatible with the deaf culture and Turkish Sign Language and could be used to determine the attitudes of deaf parents towards child rearing. In the study, it was determined that the deaf mothers' Overly-Tolerant Attitude subscale score was significantly higher than fathers, and 26-30 year old parents were found to have higher Oppressive and Authoritarian Attitude subscale scores than 36-40 year old parents. Study results were discussed in light of the literature, and the study was predicted to guide similar studies with deaf individuals.
\end{abstract}

Keywords: Turkish Sign Language, deafness, deaf parental attitudes, child rearing attitude, scale adaptation, preschool period.

\section{Giriş}

Çocukların yaşadığı topluma uyumlu bir yetişkin olmasında, anne-babalarının tutum ve davranışları etkilidir. Anne-babaların çocuk yetiştirmeye yönelik tutumları ise kendi kişisel özellikleri, çocuğa ait özellikler ve diğer pek çok faktörden etkilenebilmektedir. Çocuğun ilk çevresi olan aile ortamında karşılaştığ 1 tutumların niteliği, onun gelecek yaşamında nasıl bir yetişkin olacağının belirleyicisidir.

Genel olarak anne-baba tutumları olumlu ve olumsuz tutumlar olarak incelenebilir. Sağlıklı bir anne-baba tutumu çocuğu anlayan, değer veren, yanlışından çok doğrularını göz önünde bulunduran, yaratıcı düşünme becerileri başta olmak üzere problem çözme becerilerini geliştiren, kuralların belli ancak durum ve şarta göre esnek olabilen tutumdur. Sağlıksız tutum ise ezberci, yarışçı, idealleri doğrultusunda çocuğu belli bir kalıba sokmaya çalışan, sınırları olan ancak asla bu sınırlardan taviz vermeyen, sorumluluk duygusundan uzak ve iletişim becerileri olmayan tutumdur (Gözübüyük, 2015). Olumlu tutum olarak benimsenen demokratik tutumda, annebaba çocuğunu koşulsuz sevip kabul etmektedir. Çocuk için kurallar ve sınırlar bellidir. Böyle bir tutumla yetişen çocuk, kendisini en iyi şekilde ifade edip çözüm odaklı yetişmektedir. Çocuk hata yapabilir, ancak bu tutumda her şey çözüm odaklı ve uygun iletişim tarzı kullanıldığı için hata karşısında mantıklı bir açıklama yapılmasıyla çocukta olumlu benlik saygısı gelişir. Çocuk duygu, düşünce ve davranışları nedeniyle eleştirilmez, ebeveyn sabırlı ve hoşgörülüdür. Sınırların belli olması çocuğun karmaşa yaşamasını engeller (Oğuz ve Öğretir Özçelik, 2018). 
Olumsuz çocuk yetiştirme tutumları aşırı baskıcı veya aşırı otoriterlik, aşırı koruyuculuk, ilgisizlik, aşırı hoşgörülü olma ve tutarsızlığı içeren tutumlar olarak ele alınmaktadır. Aşırı baskıcı veya otoriter tutumda, çocuk üzerinde aşırı bir kontrol vardır, çocukla daha az ilgilenilir, kurallar yetişkinlerce konur ve nedeni açıklanmaz, çocuk kurala uymadığında cezalandırılır. Bastırılmış duygular ve davranışlar aileye gösterilmese bile çocuk çevresine ve yakın arkadaşlarına saldırganlık, öfke gibi tepkiler gösterebilir. Davranış problemleri ise çocuğun çevresi tarafından kabulünü güçleştirir. Sonuç olarak çocuk mutsuz, kaygılı, çekingen ve zayıf iletişim becerilerine sahip bir birey olarak yetişir (Santrock, 2017). Aşırı koruyucu tutumda, çocuğun yapabileceği şeyler yetişkinlerce yapılır, çocuk aşırı korunur. Bu tutumda olan ebeveynler, çocuğun yerine düşünür, çocuğun yerine karar verir, çocuk için bir yol çizer ve çocuğun bu yoldan ilerlemesini isterler. Bu şekilde yaşayan bir çocuk aynı isteği çevresinden ve arkadaşlarından da istemeye başlar. Fakat aynı özeni göremezse kendi içine kapanır, sosyal-duygusal yanı eksik kalır (Tezel Şahin ve Özyürek, 2008). İlgisiz tutumda, çocuk sevilmez, ilgi gösterilmez ve görmezden gelinir, rahatsızlık vermediği sürece problem yoktur. İlgi gösterilmeyen çocuğun güven duygusu gelişmediği için kendini rahat ifade edemezler. Aşırı hoşgörülü tutumda, çocuğa yönelik abartılmış bir sevgi gösterisi yanında sağlıksız bir ebeveyn-çocuk etkileşimi vardır, çocuğun hakları sınırsızdır. Tutarsız tutumda, anne-baba davranışlarında tutarsızdır, çocuk doğru ve yanlışı ayırt edemez (Özyürek, 2017).

Ailenin çocuk sayısı, aile yapısı, çocuğun cinsiyeti, anne-babanın eğitim durumu, mesleği, yaşı, kendi anne-baba tutumları yanında yaşadıkları kültürel değerler de çocuk yetiştirme tutumlarını etkileyebilmektedir (Tezel Şahin ve Özyürek, 2008). Bazen ebeveynler fiziksel engelli, görme veya işitme engelli olabileceği gibi normal bireylerden farklı özel durumlara sahip olabilir. Fakat bu durum onların aile kurmalarına ve anne-baba olmalarına engel değildir. Bireysel açıdan özel bir duruma sahip olsun veya olmasın, bir çocuğa sahip olduktan sonra anne-babalık tüm ebeveynlerin sorumlulukları arasındadır. Çok kültürlü toplum yapısı içinde alt kültür özelliği gösteren sağır toplumu, gündelik iletişimde işaret dilini kullanan ve sağırlığa yönelik ortak deneyimlere sahip bireylerden oluşmaktadır (Stewart 2991'den akt. Alsancak, 2018). Türkiye' de işitme engelli olmak özür olarak kabul edilmiş, fakat son zamanlarda sağır kavramı kullanılmaya başlanmıştır. İnsan konuşma sesi frekansları ( 500 ila $4000 \mathrm{~Hz}$ ) saf sesleri duyma eşiği ortalaması yetişkinlerde $25 \mathrm{~dB}-\mathrm{HL}$, çocuklarda 15 dB-HL'nin daha üzerinde olduğunda işitme kaybı olduğu kabul edilmektedir. İşaret dili ve sağırlığı konu edinen çalışmalarda işitme kaybı olanlar "sağır" olarak nitelendirilmekte, bu durum bir "engel" veya "özür" olarak görülmemektedir. Bununla birlikte sağır kavramı, iletişimde işaret dilini benimseyip kendini sağır toplumunun bir parçası olarak görenler için kullanılmaktadır (Dikyuva vd., 2015; Seven ve Göl-Güven, 2016).

Sağır toplumu, işitme yetisini kaybetmiş bireylerle birlikte, bu bireylerin işaret dili bilen işiten çocuklarına kadar geniş bir yelpazede ele alınmaktadır. Ancak, işitme kayıplı olsalar bile sözel dil ile eğitim görmüş bireyler ve sonradan işitme yetisini kaybetmiş bireyler sağır toplumunun bir ferdi olarak kabul edilmemektedir. Sağır toplumunun bir üyesi olmak, kişinin sadece işitme kayıplı olması ile değil, işaret dilini kullanması ve sağır kültürünü benimsemesi ile ilgili bir durum olarak değerlendirilmektedir (Singleton ve Tittle, 2000). Türkiye nüfusunun 3,5 milyona 
yakın olduğu belirtilen (\%0,2-\%0,3) sağır toplumunun (Alsanak, 2018) iletişim dili olarak benimsediği Türk İşaret Dili (TID), kendine özgü yapısal özellikler sergileyen ve kuşaktan kuşağa kültürel aktarım yoluyla miras bırakılan, köklü tarihe sahip doğal bir dildir. Dünyadaki diğer işaret dillerinde olduğu gibi TİD, eller ve vücudun baş, omuz, üst gövde, yüz, kaş, göz, dudak, ağız gibi bölümlerinin aktif olarak kullanılması ile işaretlenen, iletişimsel ihtiyacı karşılama amacı taşıyan, girift ve gelişmiş dilbilgisel öğeleri ve kuralları bulunan, kullanıcılarının üzerinde uzlaştığı , sistemli jestler ve mimikler dizgesidir (Zeshan, 2003; Dikyuva vd., 2015). TİD'in yetkin olmayan ilkel bir dil olduğu, beden dilindeki jestlerden oluştuğu, dilsel üretimi esnasında yalnızca ellerin kullanıldığı, sözlü dilin basit bir yansıması olduğu, dünyadaki diğer işaret dilleri ile aynı olduğu, toplumun işiten bireyleri tarafından suni olarak geliştirildiği gibi bazı bilimsellikten uzak ve önyarg1 olarak nitelendirilebilecek görüşlerle karşılaşılabilmektedir (Aslan Demir, 2016). TID diğer işaret dillerine benzer şekilde görsel-uzamsal iletişim kanalını kullanmaktadır. Konuşma dillerindeki sözcükler sesbirimsel yapıların bir araya getirilmesiyle oluşturulurken işaret dilinde sözcükler elin şekli, konumu, hareketi, yönelimi ve elin dişındaki unsurların bir araya getirilmesi ile oluşturulmaktadır. Bu bileşenlerin farklı kullanımları işaretlerin anlamsal olarak ayırt edilmesini ve değişiklik oluşturmasını sağlamaktadır (Dikyuva vd., 2015). Son yıllarda Türk toplumu tarafından ilgi çekici bulunmakta ve kullanımı giderek artmaktadır. Bu nedenle, TID'in toplumu oluşturan sağır bireylerle ilgili çalışmalarda kullanımının yaygınlaştırılması gerektiği söylenebilir.

Alan yazın tarandığı sağır anne-babaların çocuk yetiştirme tutumlarına yönelik nicel, nitel, otobiyografi ve görüşme türünde araştırmaların yapıldı̆̆ı görülmektedir. Sağır ebeveynlerin, işiten ebeveynlere göre çocuk yetiştirme tutumları, davranışları ve inanışları bakımından benzerlikleri ve farklılıkları alanda çalışan araştırmacıların ilgilendiği konulardan olmuştur (Levinger ve Orlev, 2008; Rienzi, 1990). Sağır anne babaların işiten çocukları ile işiten anne babaların işiten çocuklarının aile içindeki statüleri, fonksiyonları ve ebeveyne yaklaşımlarını konu alan bir çalışmada sağır ve işiten anne-babaların ebeveynlik tutumlarının benzerliklere sahip olduğu görülmüştür (Rienzi, 1990). Sağır anne-babaların işiten yetişkin çocuklarının tercümanlık rollerinin doğum sırası ve cinsiyet değişkenlerinin etkisinin incelendiği bir çalışmada, kız çocukların erkekler göre ve ilk doğanların küçük kardeşlere daha fazla tercümanlık rolü üstlendikleri belirlenmiştir (Moroe ve Andrade, 2018). Sağır bir ailede tek işiten birey olma durumunun bireylerin kimlik gelişimine etkisinin incelendiği bir çalışmada, bu bireylerin sağır olduklarını okula başladıktan sonra fark ettikleri, kendilerini sağır ebeveynlerinin işiten çocukları ve işiten kulakları olarak tanımladıkları belirlenmiştir (Frank, 2014). Sağır bireylerin aile, okul ve toplumdaki deneyimleri, ebeveyn ilişkileri, duygu durumu ve sosyal becerileri (Seven ve GölGüven, 2016), sağır bireylerin ebeveynlik rollerindeki zorlukları ve ebeveynlik becerilerinin (Levinger ve Orlev, 2008) incelendiği çalışmalarda, toplumda yaşadıkları güçlükler ortaya konmuştur. Yapılan çalışmalarda verilerin görüşme yoluyla elde edildiği, sağır bireyler için standart bir ölçme aracının kullanılmadığı görülmüştür.

Alan yazında işaret dillerinden biri olarak yer alan TID üzerinde (http://tid.meb.gov.tr/isaret-dilinin-gelisimi/, Erişim: 16.01.2021) çok az çalışma yapılmış olduğu görülmektedir (Arık, 2020). Ayrıca Türkiye'de özel gereksinimli çocuğu bulunan ve sözlü dil kullanan anne-babaların çocuk yetiştirme tutumlarına 
ilişkin çalışmalara rastlanmıştır (Oğuz ve Öğretir Özçelik, 2018; Sümer, Aktürk ve Helvac1, 2010; Şendoğdu, 2000; Tezel Şahin ve Özyürek, 2008), ancak sağ1r ebeveynlerin çocuk yetiştirmeye yönelik tutumlarını inceleyen yurt dişında yapılan çalışmalar bulunduğu görülmüştür (Haddadian ve Rose, 1991; Kumar ve Rao, 2008; Wanjiru, 2014). Sağır ebeveynlerin çocuk yetiştirme tutumlarının tespiti, psikososyal destek ihtiyaçlarının karşılanması ve hayatın her alanına erişilebilirliklerinin artırılması amacıyla bir ölçüm aracı geliştirilmesi/uyarlanması gerektiğine karar verilmiştir. Yeni bir ölçek geliştirmeye göre uyarlama yapmanın daha ekonomik olması, geçerliliği güvenilirliği test edilmiş ve Türkçe hazırlanmış bir ölçeğin TíD’e uyarlanmasıyla sağır bireylerle işiten bireylerin çocuk yetiştirme tutumlarındaki benzerlik ve farklılıklarının araştırılmasına imkân tanıyacağı (Nilsson vd., 2016) düşüncesinden hareketle sağır kültürüne uygun maddeleri bulunan bir ölçeğin uyarlanmasına karar verilmiştir. Yapılan bu çalışmayla alana sağır ebeveynlerin çocuk yetiştirme tutumlarının belirlenmesinde kullanılacak bir ölçme aracı kazandırılması yanında, yapılacak benzer çalışmalara da rehberlik edeceği öngörülmüştür.

\section{Araştırmanın Amacı}

Bu çalışmada Özyürek tarafından Türk örnekleminde geliştirilmiş olan anne-babaların çocuk yetiştirme tutumlarının belirlenmesine yönelik bir ölçeğin TíD'e uyarlanması amaçlanmıştır. Çalışmada aşağıdaki sorulara cevap aranmıştır:

- Ölçek Tỉ'i iletişim dili olarak kullanan sağır ebeveynlerin çocuk yetiştirme tutumlarının belirlenmesinde geçerli ve güvenilir midir?

- TİD'i iletişim dili olarak kullanan sağır ebeveynlerin çocuk yetiştirme tutumlarında cinsiyet ve yaşa göre farklılık bulunmakta mıdır?

\section{Yöntem}

Çalışmada betimsel tarama modeli kullanılmıştır. Bu modelde, grubun özelliklerinin tespiti amacıyla veri toplanarak doğal şartları bozmadan veya ortamda herhangi bir değişiklik yaptamadan ve standartlar doğrultusunda değerlendirilme yapılmaktadır (Büyüköztürk vd., 2018).

\section{Çalışma Grubu}

Araştırmanın çalışma grubunu, Türkiye genelinde 46 farklı ilde ikamet eden ve çalışmaya katılmaya gönüllü, iletişim dili olarak TİD’i kullanan, 5-6 yaş arası çocuğu bulunan, online olarak kendilerine ulaşılan 79'u kadın, 179'u erkek olmak üzere toplam 258 sağır anne-baba oluşturmaktadır. Çalışma grubunun \%15,11'i 25 yaş ve daha küçük, \%34,9’u 26-30 yaş, \%30,2'si 31-35 yaş, \%19,8'i 36 yaş ve üzeri yaş grubundadır; \%6,2'si ilkokul, \%13,6'sı ortaokul, \%64'ü lise, \%9,7'si ön lisan ve \%6,6's1 lisans mezunudur; \%21,7'si çalışmazken \%2,7'si serbest meslek, \%59,7'si işçi, \%10,9'u memur ve \% $5^{\prime}$ i profesyonel mesleğe sahiptir. Çalışma grubunun \%50'sinin tek çocuğu, \%35,3'ünün iki, \%12,8'inin üç ve \%1,9'unun dört çocuğu vardır; \%68,6's1 çekirdek aileye sahipken \%24,8'i geniş aile ve \%6,6'sı tek ebeveynlidir.

\section{Veri Toplama Araçları}

Araştırmanın verileri cinsiyet, yaş ve çocuk sayısı gibi bilgilerin yer aldığı Kişisel Bilgiler Formu ve Anne-Baba Çocuk Yetiştirme Tutumları Ölçeği (ABTÖ) A Formu kullanılarak toplanmıştır. 
ABTÖ A Formu, Özyürek (2017) tarafından okul öncesi dönemde çocuğu bulunan ebeveynlerin çocuk yetiştirme tutumlarının belirlenmesi amacıyla, 276 anne ve 268 babadan elde edilen veriler kullanılarak geliştirilmiştir. Toplam 38 madde ve üç alt boyuttan (Demokratik, Baskıcı ve Otoriter, Aşırı Hoşgörülü Tutum) oluşan ölçek beşli likert türündedir. Alt boyutlardan alınan puanın yüksekliği o boyuta ilişkin çocuk yetiştirme tutumunun daha baskın olduğunu gösterir. Ölçek alt boyutlarına ilişkin Cronbach Alfa güvenirlik katsayıları $(0,84,0,80$ ve 0,72$)$ ve Test-Tekrar Test korelasyon katsayıları $(0,720,80$ ve 0,76$)$ ölçeğin güvenilir olduğuna işaret etmiş, ilk ve son \%27'lik gruplara ait madde ortalamaları istatistiksel açıdan anlamlı bulunmuştur.

\section{Verilerin Analizi}

ABTÖ-A Formu, uyarlama aşamalarından sonra annesi, babası, eşi ve kendisi sağır olan bir model kullanılarak TIDD modalitesine uygun video formatına dönüştürülmüş ve online ortamda katılımcılarla paylaşılmıştır. Uygulama öncesinde katılımcılara araştırmanın amacı ve ölçek hakkındaki bilgiler, açıklama videosuyla verilmiş, gönüllü katılım onayları alınmıştır. Ölçeğin kullanım amacı ve ölçek maddelerinin açıklaması ve şıklarını TİD ile anlatan videoları izleyerek ifadelere katılım düzeylerine göre cevaplarını Online Form üzerinde işaretlemeleri istenmiştir. Tüm maddeleri eksiksiz dolduran katılımcıların verileri değerlendirmeye alınmıştır.

Toplanan veriler, bilgisayar ortamında analiz edilmiştir. Katılımcıların kişisel bilgileri için tanımlayıcı istatistiklerden frekans ve yüzde oranları hesaplanmıştır. ABTÖ-A TID Formunun faktör yapısının belirlenmesinde birinci düzey Doğrulayıcı Faktör Analizi (DFA) kullanılmıştır. Kategorik verilerden oluşan ölçek faktör yapısı Çaprazlama Ağırlıklandırılmış En Küçük Kareler Tekniği ile incelenmiştir. Ölçek güvenirliği Cronbach Alfa iç tutarlık katsayısı ve test yarılama yöntemiyle incelenmiştir. Ayrıca dilsel eşdeğerlik çalışması yapılmış, Türkçe ve TİD formları puanları ilişkisini hesaplanmasında Pearson Korelasyon Katsayısı kullanılmıştır.

Cinsiyet ve yaşa göre ABTÖ puanlarının analizinde normallik dağılımları dikkate alınarak Mann Whitney U testi ve tek yönlü varyans analizi (ANOVA) uygulanmıştır. Değişkenler arası fark olması durumunda, farkın kaynağı LSD Testi ile incelenmiştir.

\section{Araştırmanın Etik İzinleri}

Yapılan bu çalışmada “Yükseköğretim Kurumları Bilimsel Araştırma ve Yayın Etiği Yönergesi" kapsamında uyulması belirtilen tüm kurallara uyulmuştur. Yönergenin ikinci bölümü olan “Bilimsel Araştırma ve Yayın Etiğine Aykırı Eylemler” başlı̆̆ı altında belirtilen eylemlerden hiçbiri gerçekleştirilmemiştir.

Etik kurul izin bilgileri

Etik değerlendirmeyi yapan kurul ad1 =Karabük Üniversitesi Girişimsel Olmayan Klinik Araştırmalar Etik Kurulu

Etik değerlendirme kararının tarihi=20/09/2019

Etik değerlendirme belgesi sayı numarası=2019/14, 5 no'lu karar

\section{Bulgular}

Bu bölümde, çalışmanın birinci alt problemi olan ABTÖ-A Formunun TID'i iletişim dili olarak kullanan sağır anne-babalar için geçerli ve güvenilir olup olmadığına ilişkin bulgular ve yorumları başlıklar halinde sunulmuştur. 


\section{Dil Eşdeğer Geçerliği}

ABTÖ-A Formunun dilsel özelliklerinin incelenmesi ve TİD'e uyarlanabilmesi için Dünya Sağlık Örgütü'nün (WHO) önerdiği çeviri, uzmanlardan oluşan bir panel, geri çevirinin yapılması, ön uygulamanın yapılması ve bilişsel açıdan incelenmesi, son halin elde edilmesi işlem basamakları izlenmiştir (Çapık vd., 2018).

İleri çeviri aşaması. TİD ve sağır kültürü hakkında bilgisi olan, anadil olarak TİD'i kullanan ve her iki dili akıcı şekilde konuşan/işaretleyen, resmi bir kurumda TİD tercümanlığı yapan sertifikalı iki çevirmen belirlenmiştir. Çevirmenlerden birisine yapılacak uyarlamanın konusu, amacı ve uyarlama sürecinde yapılmak istenenlerle ilgili olarak bilgi verilmiş, diğer çevirmene süreçte yanlı çeviri yapmaması amacıyla belirtilen hususlarda bilgilendirme yapılmamıştır (Beaton vd., 2007). Çevirmenlerden birebir çeviriye değil kavramsal eşdeğerliğe dikkat etmeleri, anlaşılamayan teknik terimler, hakaret içeren ifadeler ve jargon kullanmamaları, maddelerin açık ve anlaşılır olması, çeviride sağır bireylerin görüşlerinin alınması talep edilmiştir (WHO, 2017). Çevirilerin sentezi sürecinde çeviriler anlamsal, deyimsel, kavramsal, dilsel ve bağlamsal açıdan değerlendirilerek karşılaştırılması önerilmektedir (Jesus ve Valente, 2016). Bu amaçla, çevirmenlerle online ortamda bir toplantı düzenlenmiş, ölçek maddeleri tek tek tartışılarak en uygun TID cümlesi kararlaştırılmıştır

Uzman paneli aşaması. Ölçeğin kaynak dildeki versiyonu ile hedef dile tercüme edilmiş versiyonunun değerlendirilmesi amacıyla yapılan panelde, annebaba tutumları konusunda uzman bir akademisyen, ölçek geliştirme ve uyarlama deneyimine sahip bir akademisyen, TİD tercümanlığı ve sağır kültürü ile ilgili deneyim sahibi ve Türk İşaret Dili Bilim Onay Kurulu (TIDBO) üyesi bir öğretmen yer almıştır. Uzmanların, ABTÖ-A Formunun TİD versiyonundaki 7, 8, 9, 11, 12,13, 26, 32, 33, 36 ve 38. Maddelerin formun özgün versiyonundaki maddelerle anlamsal, bağlamsal ve kavramsal olarak eşdeğer olmadığı, yeniden çevrilmesi gerektiği yönündeki görüşleri dikkate alınarak belirtilen maddeler yeniden tercüme edilmiştir. Yeniden çevirisi yapılan maddeler için uzmanların onayı alınmıştır.

Geri çeviri aşaması. İleri çeviri ve uzman paneli aşamalarından sonra oluşturulan ölçeğin orijinal formu ile eşdeğerliğinin incelenebilmesi amacıyla geri çeviri süreci yürütülmüştür. Bu süreçte, anadil olarak Türkçeyi kullanan ve her iki dili de akııı şekilde konuşan/işaretleyen, birbirinden bağımsız çalışan (Jesus ve Valente, 2016; Çapık vd., 2018), Millî Eğitim Bakanlığına bağlı işitme engellilerin devam ettiği okullarda uzun yıllar çalışmış, TİD ile ilgili sözlük yazımı, program yazımı, ders materyali yazımı, mahalli ve merkezi kurslarda eğitim görevi, mahkemelerde bilirkişilik görevi vb. faaliyetlerin yürütülmesinde görev almış iki çevirmen belirlenmiştir. Geri çeviri işleminden sonra, çevirmenlerle online ortamda düzenlenen panelde ölçeğin her bir maddesi tartışılmış, TID transkripsiyonu ve transkripsiyonun Türkçe cümlelerine karar verilerek çevirilerin sentezi oluşturulmuştur.

Ön uygulama. Çalışma grubuna ait verilerin toplanmasından önce, ileri çeviri, uzman paneli ve geri çeviri aşamalarında üzerinde çalışılan ölçeğin uygun hazırlanıp hazırlanmadığını belirleyebilmek amacıyla pilot çalışma niteliğinde bir ön uygulama yapılmıştır. Ön uygulama Kastamonu İlinde ikamet eden sağır ve TiD kullanan 5 anne ve 5 babadan oluşmuştur. Ön uygulama, odak grup görüşmesi şeklinde yapılmıştır. Ölçek hakkında bilgi verildikten sonra, gruba ABTÖ-A Formunun TID versiyonundaki video formatlı maddeler sırası ile izletilmiş ve her bir madde için 
katılımcılara madde içeriğini anlaşılır bulup bulmadıkları, eğer anlaşılmaz ise kendi sözcük ve cümleleriyle nasıl ifade edebilecekleri, maddeyle ilgili zihinlerinde neler canlandığı, hangi seçeneği işaretlendikleri ve nedeni, maddede kendilerine rahatsız eden bir ifade olup olmadığı ve varsa bunun yerine hangi sözcük veya cümleyi kullanacakları sorularak görüşleri alınmıştır. Görüşme sonrasında, araştırmacı tarafından tutulan kayıtların çözümlemesi yapılmış ve ABTÖ-A Formunun TİD çevirisi yapılmış versiyonunun ön uygulamaya katılan tüm anne-babalar tarafından doğru anlaşıldığ1 görülmüştür. Böylece ölçeğin, sağır anne-babaların çocuk yetirme tutumlarının belirlenmesinde veri toplamak için uygun olduğuna karar verilmiştir.

Ölçeğin son hali. Uyarlama aşamaları tamamlandıktan ve son kez panel uzmanlarının görüşleri alındıktan sonra, ABTÖ-A Formunun TİD versiyonunun son hali oluşturulmuştur. Ölçeğin tanıtılması ve doldurulmasıyla ilgili açıklama ifadeleri, kişisel bilgi soruları ve ölçek maddeleri annesi, babası, eşi ve kendisi sağır olan bir model tarafından işaretlenerek video formatına dönüştürülmüştür. Videolar dijital ortama yüklenmiş, online ortamda hedef kitle için hazır hale getirilmiştir.

\section{Kapsam Geçerliği}

Kapsam geçerliğinin belirlenmesinde, uzman görüşünden yararlanılmıştır. Annebaba tutumları konusunda çalışan, TỉD konusunda deneyimli $(n=3)$ ve sağır bireylere Türkçe ögrretiminde deneyimli olmak üzere toplam 5 uzmandan görüş istenmiştir. Görüşler doğrultusunda, ölçek maddelerinde gerekli düzeltmeler yapılmıştır. Uzman görüşleri ABTÖ-A TİD Versiyonu Kapsam Geçerliliği İndeksi Tablo 1'de verilmiştir.

Tablo 1

ABTÖ-A TID Versiyonunun Kapsam Geçerliliği İndeksi (n=5)

\begin{tabular}{|c|c|c|c|c|c|c|c|}
\hline Madde No & $\mathrm{NU}^{*}$ & $\mathrm{KGO}^{* *}$ & $K G^{* * * *}$ & Madde No & $\mathrm{NU}^{*}$ & $\mathrm{KGO}^{* *}$ & $\mathrm{KGI}^{* * * *}$ \\
\hline $\mathrm{m} 1$ & 5 & 1 & 1 & $\mathrm{~m} 20$ & 5 & 1 & 1 \\
\hline $\mathrm{m} 2$ & 5 & 1 & 1 & $\mathrm{~m} 21$ & 5 & 1 & 1 \\
\hline $\mathrm{m} 3$ & 5 & 1 & 1 & $\mathrm{~m} 22$ & 5 & 1 & 1 \\
\hline $\mathrm{m} 4$ & 5 & 1 & 1 & $\mathrm{~m} 23$ & 5 & 1 & 1 \\
\hline m5 & 5 & 1 & 1 & $\mathrm{~m} 24$ & 5 & 1 & 1 \\
\hline $\mathrm{m} 6$ & 5 & 1 & 1 & $\mathrm{~m} 25$ & 5 & 1 & 1 \\
\hline $\mathrm{m} 7$ & 5 & 1 & 1 & $\mathrm{~m} 26$ & 5 & 1 & 1 \\
\hline $\mathrm{m} 8$ & 5 & 1 & 1 & $\mathrm{~m} 27$ & 5 & 1 & 1 \\
\hline m9 & 5 & 1 & 1 & $\mathrm{~m} 28$ & 5 & 1 & 1 \\
\hline m10 & 5 & 1 & 1 & $\mathrm{~m} 29$ & 5 & 1 & 1 \\
\hline m11 & 5 & 1 & 1 & $\mathrm{~m} 30$ & 5 & 1 & 1 \\
\hline $\mathrm{m} 12$ & 5 & 1 & 1 & $\mathrm{~m} 31$ & 5 & 1 & 1 \\
\hline m13 & 4 & 0,6 & 0,80 & $\mathrm{~m} 32$ & 5 & 1 & 1 \\
\hline m14 & 5 & 1 & 1 & $\mathrm{~m} 33$ & 4 & 0,6 & 0,80 \\
\hline m15 & 5 & 1 & 1 & $\mathrm{~m} 34$ & 5 & 1 & 1 \\
\hline m16 & 5 & 1 & 1 & m35 & 5 & 1 & 1 \\
\hline $\mathrm{m} 17$ & 5 & 1 & 1 & $\mathrm{~m} 36$ & 5 & 1 & 1 \\
\hline $\mathrm{m} 18$ & 5 & 1 & 1 & m37 & 5 & 1 & 1 \\
\hline m19 & 5 & 1 & 1 & $\mathrm{~m} 38$ & 5 & 1 & 1 \\
\hline
\end{tabular}


Tablo 1'de, maddelerin kapsam geçerlilik indeksi 0,80-1 arasında olduğu görüldüğünden veri toplama öncesinde atılan madde olmamıştır. Kapsam uygunluğu ölçek içerik indeksinin 0.98 olduğu belirlenmiş, buna göre uzmanların ölçek maddeleri konusunda görüş birliği sağladığı görülmüştür. Ölçeğin bir bütün olarak ve madde bazında içerik geçerliği sağlandığından (Çapık vd., 2018) ölçekten herhangi bir madde çıkarılmamıştır.

\section{Yapı Geçerliği}

Ölçeğin üç boyuttan oluşan 38 maddelik yapısının doğrulanıp doğrulanmadığını değerlendirme için uygulanan DFA sonrası Path Diyagramı Şekil 1'de görülmektedir.

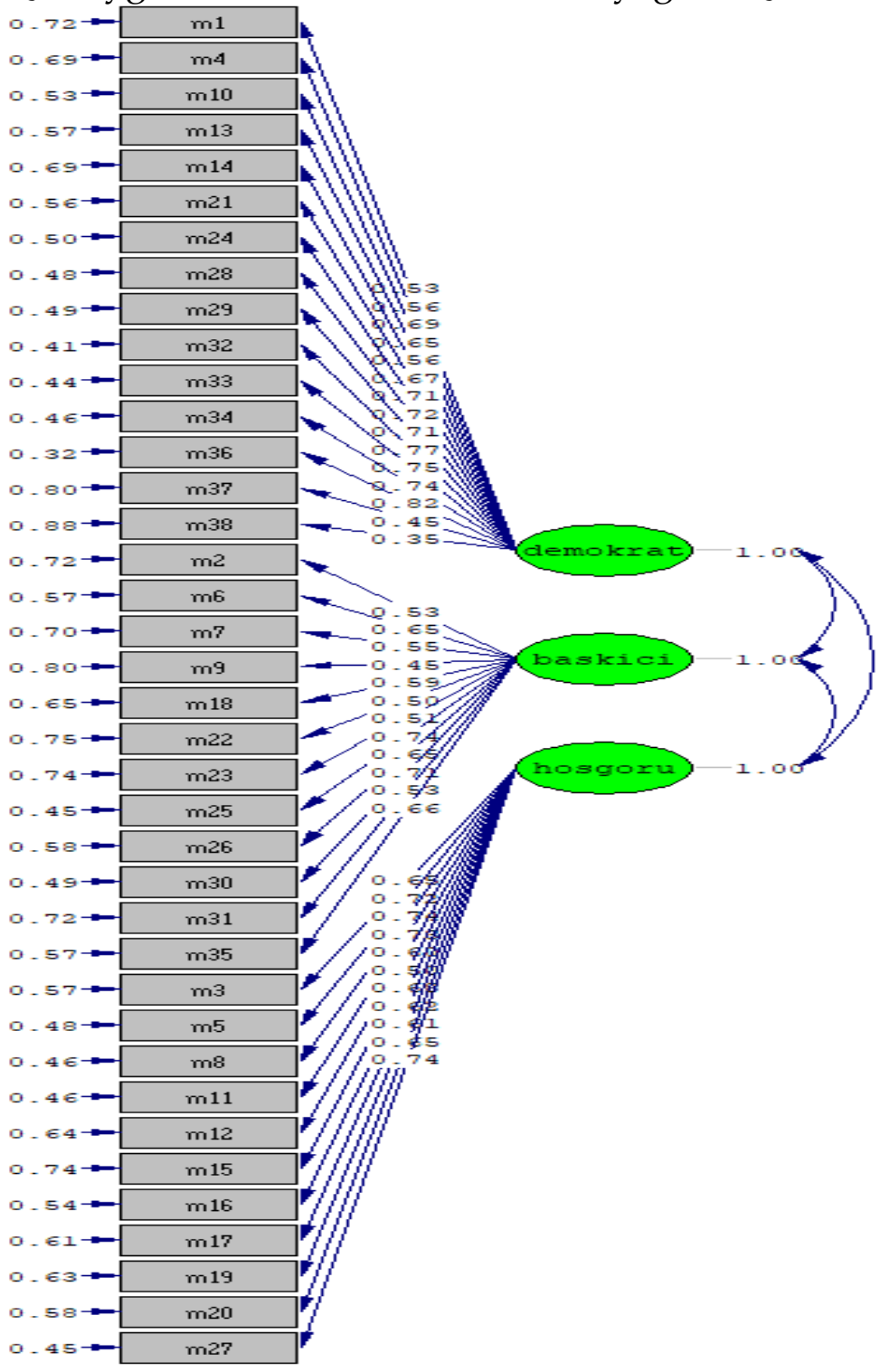

Şekil 1. Path diagramı

Şekil 1'de ölçek uyum indeksleri $\chi^{2}=2138.99, X^{2} / \mathrm{sd}=3.23, \mathrm{RMSEA}=0.076$, $\mathrm{CFI}=0.94, \mathrm{IFI}=0.94, \mathrm{NNFI}=0,93$ ve $\mathrm{NFI}=0,91$ olup faktör yapısını ortaya koyan modelin gözlenen değişkenleri ve faktörler arası ilişkiyi gösteren tüm katsayıların yüksek düzeyde olduğu görülmektedir. DFA ile hesaplanan uyum istatistiklerine göre, ölçeğe ait önceden belirlenmiş olan yapının yeni verilerle uyum sağladığı görülmektedir. 
Birinci düzey DFA bulgularına göre, istatistiksel açıdan anlamlı bulunmayan $t$ değerine sahip maddelere ilişkin veriler Tablo 2' de görülmektedir.

Tablo 2

Ölçek Maddeleri Regresyon ve t Değerleri

\begin{tabular}{llcllcc}
\hline \multicolumn{1}{c}{ Madde } & $\mathrm{R}$ & $\mathrm{t}$ & \multicolumn{1}{r}{ Madde } & $\mathrm{R}$ & $\mathrm{t}$ \\
\hline $\mathrm{m} 1$ & 0.49 & 8.91 & $\mathrm{~m} 18$ & 0.65 & 10.14 \\
$\mathrm{~m} 4$ & 0.51 & 9.47 & $\mathrm{~m} 22$ & 0.62 & 8.18 \\
$\mathrm{~m} 10$ & 0.67 & 12.36 & $\mathrm{~m} 23$ & 0.56 & 8.47 \\
$\mathrm{~m} 13$ & 0.58 & 11.50 & $\mathrm{~m} 25$ & 0.68 & 13.54 \\
$\mathrm{~m} 14$ & 0.58 & 9.45 & $\mathrm{~m} 26$ & 0.69 & 11.31 \\
$\mathrm{~m} 21$ & 0.58 & 11.81 & $\mathrm{~m} 30$ & 0.65 & 12.85 \\
$\mathrm{~m} 24$ & 0.66 & 12.80 & $\mathrm{~m} 31$ & 0.60 & 8.82 \\
$\mathrm{~m} 28$ & 0.68 & 13.12 & $\mathrm{~m} 35$ & 0.66 & 11.50 \\
$\mathrm{~m} 29$ & 0.59 & 12.94 & $\mathrm{~m} 3$ & 0.89 & 11.35 \\
$\mathrm{~m} 32$ & 0.62 & 14.33 & $\mathrm{~m} 5$ & 0.98 & 12.90 \\
$\mathrm{~m} 33$ & 0.72 & 13.82 & $\mathrm{~m} 8$ & 0.92 & 13.34 \\
$\mathrm{~m} 34$ & 0.67 & 13.54 & $\mathrm{~m} 11$ & 0.98 & 13.24 \\
$\mathrm{~m} 36$ & 0.77 & 15.94 & $\mathrm{~m} 12$ & 0.85 & 10.09 \\
$\mathrm{~m} 37$ & 0.56 & 7.33 & $\mathrm{~m} 15$ & 0.57 & 8.28 \\
$\mathrm{~m} 38$ & 0.41 & 5.54 & $\mathrm{~m} 16$ & 0.77 & 11.98 \\
$\mathrm{~m} 2$ & 0.54 & 8.78 & $\mathrm{~m} 17$ & 0.69 & 10.67 \\
$\mathrm{~m} 6$ & 0.63 & 11.43 & $\mathrm{~m} 19$ & 0.66 & 10.43 \\
$\mathrm{~m} 7$ & 0.56 & 9.15 & $\mathrm{~m} 20$ & 0.82 & 11.15 \\
$\mathrm{~m} 9$ & 0.58 & 7.36 & $\mathrm{~m} 27$ & 0.87 & 13.43 \\
\hline
\end{tabular}

Tablo 2'de görüldüğü gibi regresyon katsayıları ve $t$ değerleri anlamlı $(t>1,92)$ bulunmuş ve model doğrulanmıştır. Tüm maddeler, ölçekteki yerini korumuştur.

\section{Güvenirlik Çalışması}

Ölçeğin alt boyutlar için Cronbach Alfa Güvenirlik Katsayıları (Demokratik Tutum:0,91, Baskıcı ve Otoriter Tutum: 0,86 ve Aşırı Hoşgörülü Tutum: 0,89) güvenirlik düzeyinin yüksek olduğunu göstermiştir.

Çalışmanın ikinci alt problemi olan TİD'i iletişim dili olarak kullanan sağır ebeveynlerin çocuk yetiştirme tutumlarında cinsiyet ve yaşa göre farklılık bulunup bulunmadığına ilişkin bulgular Tablo 4 ve Tablo 5 'te sunulmuştur.

Tablo 3

Cinsiyete Göre ABTÖ Puanları M.W.U Testi Sonuçları

\begin{tabular}{llccccc}
\hline & & $\mathrm{N}$ & Ortalama & $\mathrm{S}$ & $\mathrm{U}$ & $\mathrm{p}$ \\
\hline \multirow{2}{*}{ Demokratik Tutum } & Anne & 179 & 60,36 & 10,26 & $-0,557$ & 0,578 \\
& Baba & 79 & 61,08 & 7,74 & & 0,758 \\
\hline \multirow{2}{*}{ Baskıcı ve Otoriter Tutum } & Anne & 179 & 45,57 & 8,45 & 0,308 & 0 \\
& Baba & 79 & 45,24 & 7,05 & & \\
\hline \multirow{2}{*}{ Aşırı Hoşgörülü Tutum } & Anne & 179 & 34,70 & 9,54 & $-2,893$ & $0,004^{*}$ \\
& Baba & 79 & 31,60 & 9,22 & & \\
\hline
\end{tabular}
${ }^{*} \mathrm{p}<0,05$

Tablo 3'te, sağır annelerle babaların ABTÖ Aşırı Hoşgörülü Tutum alt boyutundan aldıkları puanlar arası farkın manidar olduğu görülmektedir $(p<0,05)$. 
Annelere ait ABTÖ Aşırı Hoşgörülü Tutum alt boyut puanı (Ort.: 34,70), babaların puanından (Ort.: 31,60) daha yüksektir.

Tablo 4

Yaşa Göre ABTÖ Puanları ANOVA Sonuçlarn

\begin{tabular}{llccccc}
\hline & $\mathrm{N}$ & Ortalama & $\mathrm{S}$ & $\mathrm{F}$ & $\mathrm{p}$ \\
\hline & 25 yaş ve daha küçük & 39 & 60,05 & 12,33 & 0,692 & 0,598 \\
Demokratik & 26-30 yaş & 90 & 61,23 & 8,38 & & \\
Tutum & 31-35 yaş & 78 & 60,19 & 9,17 & & \\
& 36-40 yaş & 41 & 59,51 & 10,28 & & \\
\hline \multirow{2}{*}{ Baskıcı ve } & 46 yaş ve daha büyük & 10 & 64,40 & 7,21 & & \\
Otoriter & 25 yaş ve daha küçük & 39 & 44,82 & 9,66 & 2,463 & $0,046^{*}$ \\
Tutum & 26-30 yaş & 90 & 47,38 & 6,40 & & \\
& 31-35 yaş & 78 & 44,24 & 7,89 & & \\
& 36-40 yaş & 41 & 43,75 & 9,22 & & \multirow{2}{*}{ Fark: $2-3,4$} \\
\hline & 46 yaş ve daha büyük & 10 & 47,40 & 8,09 & 0,486 \\
Aşırı & 25 yaş ve daha küçük & 39 & 32,56 & 10,30 & 0,864 & \\
Hoşgörülü & 26-30 yaş & 90 & 34,60 & 9,81 & & \\
Tutum & 31-35 yaş & 78 & 33,38 & 8,77 & & \\
& 36-40 yaş & 41 & 32,80 & 9,47 & & \\
\hline
\end{tabular}

${ }^{*} \mathrm{p}<0,05$

Tablo 4'te, çalışma grubunun yaşlarına göre ABTÖ Baskıcı ve Otoriter Tutum alt boyut puanları farkının manidar olduğu görülmektedir $(p<0,05)$. Post Hoc LSD Testi sonucunda 26-30 yaşındaki katılımcıların Baskıcı ve Otoriter Tutum alt boyut puanı (Ort.: 47,38) 31-35 yaş (Ort.: 44,24) ve 36-40 yaşındakilerin puanına (Ort.:43,70) göre anlamlı düzeyde yüksek olduğu görülmüştür.

\section{Tartışma, Sonuç ve Öneriler}

$\mathrm{Bu}$ çalışmada 5-6 yaşında çocuğu olan sağır anne-babaların çocuk yetiştirme tutumlarını belirlemeye yönelik bir ölçek uyarlama aşamalarına yer verilmiştir. Normal işiten anne-babalar için Özyürek (2017) tarafından geliştirilen Anne-Baba Tutum Ölçeği (ABTÖ) A Formu, Türk İşaret Dilini kullanan sağır anne-babaların çocuk yetiştirme tutumlarını belirlemek amacıyla uyarlanmıştır.

Geliştirilen ya da uyarlanan bir ölçme aracının geçerli olduğunu söyleyebilmek için, ölçülen yapıların özelliklerine uygun olması, bu yapıları başka değişkenlerle karıştırmadan doğru ölçmesi ve geçerlik katsayısının kabul edilebilir ranjlarda olması gerekmektedir. Bununla birlikte, geçerlik verileri ile güvenirlik verilerinin birlikte değerlendirilmesi ve yorumlanması gerekmektedir (Gözen, 2013).

Ölçme aracı geliştirme ve uyarlama sürecinde genel olarak kapsam geçerliği, kriter geçerliliği, geçerlik, kestirimsel geçerlilik, uyum geçerliliği, yapı geçerliliği ve görünüş geçerliliği gibi geçerlilik türleri kullanılmaktadır (Büyüköztürk, 2003). Bu çalışmada öncelikli olarak dilsel uyarlama süreci işletilmiştir. Kapsam geçerliliğinin belirlenebilmesi için uzman görüşü alınmış ve uzmanların ölçek maddeleriyle ilgili olarak görüş birliğine vardıkları belirlenmiştir. KGO, -1 (mutlak red) ile +1 (mutlak kabul) arasında değer almaktadır ve katılımcıların tümü bir ölçek maddesini “Uygun” olarak derecelendirdiğinde o maddeye ait KGO değeri 1 olur. Fakat hata payı ya da 
şans eseri olabileceği dikkate alınarak bu değer 0,99 kabul edilmiştir. Bu durumda katılımcıların yarısından fazlası ölçekte yer alan bir maddeyi "Uygun" olarak derecelendirdiğinde KGO 0 ile 0,99 arası bir değer alacaktır. KGO eşitliğine göre; uzmanların yarısı ölçek maddesi için "Uygun" görüşü bildirdiğinde $\mathrm{KGO}=0$, yarısından fazlası "Uygun" görüş bildirdiğinde KGO>0 ve yarısından azı "Uygun" görüş bildirdiğinde KGO<0 olacaktır. Eğer KGO oranı 0 (sıfır) veya negatif (sıfırdan küçük) değer alıyorsa bu şekilde bir değere sahip maddenin kapsam geçerliliği olmadığından elenir (Ayre ve Scally 2014). Ölçeğin tüm maddelerinin anne-aba tutumları ile ilgili ölçülmek istenen yapıyı değerlendirmede, çeviri ve geri çeviri ile uzman paneli sonucunda içerik geçerliğine sahip olduğu tespit edilmiştir.

Yapı geçerliliği, geliştirilen ya da uyarlanan ölçme aracının amaçlananı ne derecede doğru ölçtüğünü, bu aracın kullanımı ile elde edilen puanların ne anlama geldiğini, neyle ilintili olduğunu açıklamaya yarayan analiz sürecidir (Özgüven, 1994). Ölçek geliştirme ve uyarlama süreçlerinde genelde ölçülmesi hedeflenen yaprya ilişkin boyut belirlemek amacıyla Açımlayıcı Faktör Analizi (AFA), maddelerin belirlenen faktörler/boyutlarla temsil düzeyini belirlemek için DFA kullanılmaktadır. DFA ile çok sayıda gözlenebilir değişkenin yer aldığı faktörlerden oluşmuş faktöryel modelin gerçek verilerle uyum düzeyini değerlendirmek amaçlanır (Evci ve Aylar, 2017). Çalışmada, ölçeğin özgün versiyondaki tüm boyut ve maddelerin aynı kalması nedeniyle yalnızca DFA uygulanmıştır. Birinci düzey DFA bulguları incelendiğinde tüm madde değerlerinin anlamlı olduğu görülmüştür. Ölçek faktör yapısını gösteren model, gözlenen değişkenlerle faktörleri arasındaki ilişki katsayıları yüksek düzeyde bulunmuştur. DFA uyum istatistiklerine göre, ölçeğin orijinal yapısının yeni verilerle uyum sağladığı görülmüştür.

Güvenirlik katsayılarının hesaplanmasında test-tekrar test, eşdeğer formlar, iç tutarlılık ve puanlama tutarlılı̆̆1 yöntemleri kullanılmaktadır. Likert tipi ölçeklerde güvenirlik katsayısının olabildiğince 1'e yakın olması yeterlilik için gerekli görülmektedir (Tezbaşaran, 1997). Elde edilen sonuçlara göre, ABTÖ-A Formu TİD versiyonunun güvenirliğinin yüksek olduğuna karar verilmiştir. Ölçeğin sağır kültürüne uygun versiyonunun Anne-Baba Çocuk Yetiştirme Tutumları Ölçeği Türk İşaret Dili Versiyonu (ABTÖ-TID) olarak isimlendirilmesi uygun görülmüştür.

Çalışmada, sağır annelerin Aşırı Hoşgörülü Tutum alt boyut puanının babalara göre, 26-30 yaşındaki ebeveynlerin Baskıcı ve Otoriter Tutum alt boyut puanlarının 3640 yaşındaki ebeveynlere göre anlamlı düzeyde yüksek bulunmuştur. Tezel Şahin ve Özyürek (2008), okul öncesi yaş çocuğu olan ebeveynlerle yaptıkları çalışmada annelerin babalara göre demokratik tutum oranlarının daha yüksek olduğunu belirlemişlerdir. Yine annelerin babalardan daha demokratik olduğu vurgulanmıştır. Şendoğdu (2000) çalışmasında, genç babaların yaşı daha büyük olanlara kıyasla baskıc1 tutumunun düşük olduğunu belirlemişlerdir. Haddadian ve Rose (1991), işitme engelli çocuğa sahip anne ve babalarla yaptıkları çalışmada, anne ve babaların tutumları arasında anlamlı bir farklılık olmadığını belirlemişlerdir. Bu bulgular, araştırma bulgularında yaşa ve anne-baba olma durumuna göre elde edilen veriler açısından farklılık göstermektedir. Seven ve Göl-Güven (2016), Levinger ve Orley (2008), sağır bireylerin hem toplumsal uyum hem de ebeveynlik rollerinde çeşitli zorluklar yaşadıklarını belirlemişlerdir. Çocukların yaşlarının küçük olması yanında ebeveynlerin sağır olmalarına bağlı çocuklarıyla yaşadıkları iletişim sorunları, 
tutumları üzerinde etkili olmuş olabilir. İşitme engelli çocuğa sahip anne ve babaların öğrenim durumu, mesleği ve çocuk sayısı gibi değişkenlerin tutumlarını etkilediği (Wanjuri, 2014); anne-babaların erkek çocuklarına karşı daha olumlu tutumlar sergiledikleri belirlenen Hindistan'da yapılan bir başka çalışma ise (Kumar ve Rao, 2008) çocuğa ilişkin özellikler yanında ailevi veya kültürel özelliklerin de tutumlar üzerinde etkili olabileceğini ortaya koymaktadır. Türk toplumu kültürel yapısında engel durumundan bağımsız olarak babaların otoriter görülmesi, çocuklara yönelik tutumlarını da bu yönde etkilemiş olabilir.

Türk İşaret Dili, sağır bireyler için iletişim aracıdır. Her bireyin olduğu gibi sağır bireylerin de evlenip çocuk sahibi olduğunda çocuklarını yetiştirirken benimsedikleri tutumlar, çocuklarının gelişiminde etkili olacaktır. Bu nedenle, sağır anne-babaların baskın çocuk yetiştirme tutumlarının belirlenerek konuyla ilgili yapılacak eğitsel çalışmalara yön verilebilir. Fakat sağır bireylerle ilgili bu tür verilerin elde edilmesi, iletişim engelleri ve ölçüm araçlarının kısıtlı olmasından dolayı araştırmacılar için oldukça güçtür. Bu çalışmada, 5-6 yaşında çocuğa sahip sağır ebeveynlerin çocuk yetiştirme tutumlarını belirleyebilmek amacıyla bir ölçek uyarlama çalışması yapılmış ve sağır anne-babaların çocuk yetiştirme tutumları karşılaştırılmıştır. Çalışmada elde edilen ve ABTÖ-TİD olarak isimlendirilen 38 madde ve üç alt boyuttan oluşan ölçeğin, sağır ebeveynlerin çocuk yetiştirme tutumlarını belirlemeye yönelik betimsel veya deneysel vb. pek çok çalışmada kullanılabilecek olması yanında, sağır ebeveynlerle ilgili ölçek geliştirme veya farklı projeler için araştırmacılara örnek teşkil edeceği de öngörülmektedir. Ölçek uyarlama dışında, farklı yaşlarda çocuğu olan sağır annelerin ve babaların çocuk yetiştirme tutumlarını belirlemeye yönelik ölçek geliştirme çalışmaları da yapılabilir. Çalışmaya yalnızca okul öncesi çocuğa sahip sağır anne-babaların dahil edilmiş olması, orijinal ölçeğin bu yaş grubu çocuğa sahip anne-babalara yönelik olmasından kaynaklanmaktadır ve bu çalışmanın sınırlığı olarak ele alınabilir. Farklı yaşlarda çocuğu olan sağır annebabaların çocuk yetiştirme tutumlarının belirlenmesine yönelik ölçek uyarlama veya geliştirme çalışması yapılarak çocuk yetiştirme tutumları da çeşitli sosyo demografik özellikler dikkate alınarak incelenebilir.

Anne-babalarla ilgili pek çok çalışma olmasına rağmen farklı özel gereksinim türlerine sahip anne-babalara yönelik çalışmaların kısıtlı sayıda olduğu, geçerlik ve güvenirliği yapılmış ölçme araçlarının da yeterli olmadığı görülmektedir. Ölçek geliştirme sürecinde, araştırmacıların işitme veya görme gibi sınırlılıkları nedeniyle özel gereksinimli aileleri de dikkate alarak çalışmalar yapmalarının alana önemli katkı sağlayacağ1 düşünülmektedir. İşitme veya görme gibi farklı sorunları bulunan ve toplumdaki anne-babalık başta olmak üzere pek çok rolü üstlenen bireylere yönelik akademik, nitelikli çalışmalar yapılabilecektir.

Son olarak; Türk kültürüne özgü ve sağır toplumu için iletişim aracı olarak kullanılan TİD ile ilgili çalışmalar artırılabilir. TID konusunda, Türkçe'nin Türk Dünyası iletişim dili olarak kullanılması gibi Türk Dünyası sağır toplumu için iletişim dili olarak kullanılıp kullanılamayacağına yönelik çalışmalar yapılabilir. Bu konuda disiplinler arası bir çalışmanın alana önemli bir katsı sunacağı söylenebilir.

\section{Kaynakça}

Alsancak, F. (2018). Sağır toplumunun sosyal dişlanma sorunları. Uluslararası sosyal Araştırmalar Dergisi, 11(58), 423-430. https:/ / doi.org/10.17719/jisr.2018.2556 
Arık, E. (2020). Türk İşaret Dili'nde sözdizime deneysel bir yaklaşım. Bilig, Türk Dünyası Sosyal Bilimler Dergisi, 94, 75-96. https:// doi.org/10.12995/bilig.9404

Aslan Demir, S. (2016). Sessizliğin dili: Türk işaret diline dair gözlemler. İçinde E. Arık (Der.), Ellerle konuşmak: Türk işaret dili araştırmaları (ss. 141-156). İstanbul: Koç Üniversitesi.

Ayre, C. and Scally, A. J. (2014). Critical values for Lawshe's content validity ratio: revisiting the original methods of calculation. Measurement and Evaluation in Counseling and Development, 47(1), 79-86.

https:// doi.org/10.1177/0748175613513808

Beaton, D., Bombardier, C., Guillemin, F. and Ferraz, M. B. (2007). Recommendations for the cross-cultural adaptation of the DASH and quick DASH outcome measures. Institute for Work and Health, 1-45.

Büyüköztürk, Ş. (2003). Sosyal bilimler için veri analizi el kitabı, Ankara: Pegem.

Büyüköztürk, Ş., Akgün, Ö.E., Karadeniz, Ş., Demirel, F. ve Kılıç Çakmak, E. (2018). Ĕ̆itimde bilimsel araştırma yöntemleri, Ankara: Pegem. https:// doi.org/10.14527/9789944919289

Çapık, C., Gözüm, S. ve Aksayan, S. (2018). Kültürlerarası ölçek uyarlama aşamaları, dil ve kültür uyarlaması: güncellenmiş rehber, Florence Nightingale Hemşirelik Dergisi. 26(3), 199-210. https:/ / doi.org/10.26650/FNJN397481

Dikyuva, H. Makaroğlu, B. ve Arık, E. (2015). Türk işaret dili dil bilgisi kitabı, Ankara: T.C. Aile ve Sosyal Politikalar Bakanlı̆̆1.

Evci, N. ve Aylar, F. (2017). Derleme: Ölçek geliştirme çalışmalarında doğrulayıcı faktör analizinin kullanımı. Sosyal Bilimler Dergisi, 10, 389-412. https:// doi.org/10.16990/SOBIDER.3386

Frank, A. (2014). The identity development of the only hearing child in an all Deaf family. JADARA, 49(1), 4-26.

Gözen, G. (2013). Geçerlik. İçinde E. Tavşanc1l (Ed.), Psikolojik test ve değerleme; testlere ve ölçemeye giriş (ss.172-207). Ankara: Nobel.

Gözübüyük, N. (2015). Okul öncesi dönem çocuklarında davranış sorunlarının faktör analizi ve aşamalı kümeleme analizi sonuçlarının karşılaştırılması, Eğitimde ve Psikolojide Ölçme ve Değerlendirme Dergisi, 1(2), 65-71.

Haddadian, A. and Rose, S. (1991. An investigation of parents' attitudes and the communication skills of their deaf chidren, American Annals of the Deaf, 136(3), 273-277. Doi: 10.1353/aad.2012.064.66.

http:/ / tid.meb.gov.tr/isaret-dilinin-gelisimi/.(2020). Türkiye' de işaret dilinin gelişimi. Erişim: 16.01.2021

Jesus, L. M. T. and Valente, A. R. (2016). Cross-cultural adaptation of health assessment instruments. http:// sweet. ua.pt/lmtj/lmtj/ Jesus Valente 2016. Pdf.

Kumar, S. and Rao, G. (2008). Parental attitudes towards children with hearing impairment, Asia Pasific Disability Rehabilitation Journal, 19(2), 111-117.

Levinger, M. and Orlev, L. (2008). What deaf parents "hear". The Journal of International Social Research, 1(4), 413-430.

Moroe, N.F. and Andrade, V. (2018). Hearing children of deaf parents: Gender and birth order in the delegation of the interpreter role in culturally Deaf families. 
African Journal of Disability, 7(0), 365-375.

https:// doi.org/10.4102/ajod.v7i0.365

Nilsson, J., Gardulf, A. and Lepp, M. (2016). Process of translation and adaptation of the nurse professional competence (NPC) Scale. Journal of Nursing Education and Practice, 6(1), 100- 103. https:// doi.org/10.5430/jnep.v6n1p100

Oğuz, F. ve Öğretir Özçelik, A.D. (2018). Ergenlerde algılanan anne baba tutumu ile madde bağımlılı̆̆ arasındaki ilişkinin incelenmesi. Uluslararası Sosyal Araştırmalar Dergisi, 11 (58), 535-543. https:// doi.org/10.17719/jisr.2018.2567

Özgüven, İ. E. (1994). Psikolojik testler. Ankara: Yeni Doğuş.

Özyürek, A. (2017). Okul öncesi çocuğa sahip anne-babalara yönelik “Çocuk yetiştirmeye ilişkin anne-baba görüşleri ölçeği" ve "Anne-baba tutum ölçeği" geliştirme çalışması. Uluslararası Erken Çocukluk Eğitimi Çalışmaları Dergisi, 2(1), 26-38.

Rienzi, B. M. (1990). Influence and adaptability in families with deaf parents and hearing children. American Annals of the Deaf, 135(5), 402-408. https:// doi.org/10.1353/aad.2012.0463

Santrock, W. J. (2017). Yaşam boyu gelişim (Çev.: G. Yüksel) Ankara: Nobel.

Seven, Y. ve Göl-Güven, M. (2016). Bir dil iki dünya: Sağır anne babanın işiten çocuğu olmak (ss.389- 410). E. Arık, (Der.), Ellerle konuşmak: Türk işaret dili araştırmaları. İstanbul: Koç Üniversitesi.

Singleton, J. and Tittle M. (2000). Deaf parents and their hearing children. Journal of Deaf Studies and Deaf Education, 5(3), 221- 236. https:// doi.org/10.1093/deafed/5.3.221

Sümer, N., Aktürk, G. ve Helvacı, E. (2010). Anne-baba tutum ve davranışlarının psikolojik etkileri: Türkiye' de yapılan çalışmalara toplu bakış. Türk Psikoloji Yazıları, 42-59.

Şendoğdu, M. C. (2000). Anaokuluna devam eden 5-6 yaş çocuklarının anne-babalarımı algılamaları ile anne babalarm kendi tutumlarm algılamaları arasındaki ilişki. Yüksek lisans tezi, Gazi Üniversitesi, Ankara.

Tezbaşaran, A. (1997). Likert tipi ölçek geliştirme kılavuzu. Ankara: Türk Psikologlar Derneği.

Tezel Şahin, F. ve Özyürek, A. (2008). 5-6 yaş grubu çocuğa sahip ebeveynlerin demografik özelliklerinin çocuk yetiştirme tutumlarına etkisinin incelenmesi, Türk Ĕ̆itim Bilimleri Dergisi, 6(3), 395-414.

Wanjiru, T. N. (2014). Parental attitudes towards children with hearing impairment and academic performance: a case of Kabui School for the deaf githunguri district, Kiambu county, Kenya. Master Thesis, Kenyatta University.

Zeshan, U. (2003). Aspects of Türk işaret dili. Sign Language and Linguistics, 6(1), 4375. https://doi.org/10.1075/sll.6.1.04zes

\section{Summary}

\section{Introduction}

Parents' attitudes and behaviors are effective for children's development and adaptation to society. Parents' attitudes towards child rearing can be affected by their personal characteristics, characteristics of the child and many other factors. In all 
families consisting of individuals with disabilities or normal developmental characteristics, parenting is the responsibility of each parent. Deaf community is called as the community consisting of individuals who use Turkish Sign Language (TSL) in daily communication.

Turkish Sign Language (TSL), adopted as the communication language by the deaf community in Turkey, which is between $0.2 \%$ and $0.3 \%$ of the population, is a natural language with unique structural features and inherited through cultural transmission from earlier generations with a long history. Similar to other sign languages, TSL is signed by the active use of the hands and certain parts of the body such as the head, shoulder, upper body, face, eyebrows, eyes, lips, and mouth, with intricate and advanced grammatical elements and rules that aim to fulfill communication needs, and it is a system of systematic gestures and mimics agreed by all users. In the literature, only a few studies were conducted on TSL, which is one of the sign languages (Ar1k, 2020). Furthermore, there are studies on child-rearing attitudes of parents with special needs children and speak verbal language; however, literature review revealed no study on child rearing attitudes of deaf parents. It was decided that a measurement tool should be developed/adapted to determine the child rearing attitudes of deaf parents, to fulfill their psychosocial support requirements, and to improve their accessibility to all areas of life.

The aim of this study designed in the description screening model is to make a scale adaptation and to determine the attitudes of deaf parents to raise children in order to examine the child rearing attitudes of deaf parents who have children at the age of 5-6.

\section{Method}

The study group of the study consists of 258 deaf parents with children in the target age group who use Turkish Sign Language as the communication language. In order to collect the data, the Parent Attitude Scale (PAS)-A form was used. The scale was translated into Turkish Sign Language (TSL) and Confirmatory Factor Analysis (CFA) was performed. Cronbach alpha was calculated to determine the reliability of the scale.

The PAS-A Form linguistic equivalence study was conducted, and Pearson Correlation Coefficient was employed to calculate the correlation between Turkish language and TSL form scores. Mann-Whitney $U$ test and one-way analysis of variance (ANOVA) were employed to analyze the PAS scores based on gender and age, due to normal distribution. In case of difference between the variables, the source of the difference was investigated with the LSD Test.

\section{Results and Discussion}

Validity tests such as content validity, criterion validity, predictive validity, agreement validity, construct validity and face validity are frequently used in measurement instrument development and adaptation processes. In the present study, the linguistic adaptation process was primarily conducted. To determine content validity, expert opinions were obtained, and it was determined that there was an agreement between the experts about the scale items.

In the study, only Confirmatory Factor Analysis (CFA) was conducted since all dimensions and items in the original scale remained the same. The review of the firstlevel CFA findings revealed that all item values were significant. The model that 
reflected the factor structure exhibited high correlation coefficients between the variables and related factors. Based on the CFA fit statistics, it was observed that the original structure of the scale was consistent with the new data. Turkish Sign Language is a medium of communication for deaf individuals. Similar to all individuals, the attitudes adopted by deaf individuals in their marriages and raising their children will affect the development of their children. However, collecting such data from deaf individuals is quite difficult for researchers. In the present study, a scale was adapted to Turkish language to determine the child-raising attitudes of deaf parents with children aged 5-6 years, and the child raising attitudes of deaf parents were compared.

It was concluded that the 38-item PAS-A Version of the TSL Version was compatible with the deaf culture and TSL and could be used to determine the attitudes of deaf parents to child rearing. In the study, it was determined that the deaf mothers' Overly-Tolerant Attitude subscale score was significantly higher than fathers, and 2630 year old parents were found to have higher Oppressive and Authoritarian Attitude subscale scores than 36-40 year old parents. Study results were discussed in light of the literature, and the study was predicted to guide similar studies with deaf individuals.

\section{Pedagogical Implications}

The parents' attitudes have quite effects on child development. The deaf parents use sign language as communication language. Therefore, data collect is difficult about this subject in academic research. In this study, a parents attitudes scale is addressed of appropriate for Turkish Sign Language. The parents' attitudes scale for deaf parents will be have use for assessing their child rearing attitudes.

\section{Araştırmanın Etik Taahhüt Metni}

Yapılan bu çalışmada bilimsel, etik ve alıntı kurallarına uyulduğu; toplanan veriler üzerinde herhangi bir tahrifatın yapılmadığı, karşılaşılacak tüm etik ihlallerde “Cumhuriyet Uluslararası Eğitim Dergisi ve Editörünün” hiçbir sorumluluğunun olmadığı, tüm sorumluluğun Sorumlu Yazara ait olduğu ve bu çalışmanın herhangi başka bir akademik yayın ortamına değerlendirme için gönderilmemiş olduğu sorumlu yazar tarafından taahhüt edilmiştir.

\section{Authors' Biodata/ Yazar Bilgileri}

Hasan Hüseyin SAÇI, MEB Kastamonu Rehberlik ve Araştırma Merkezi'nde özel eğitim öğretmeni olarak çalışmaktadır. Karabük Üniversitesi Sağlık Bilimleri Enstitüsü'nde Yüksek Lisans Tez çalışmasını tamamlamıştır.

Hasan Hüseyin Saçı is a special education teacher at Kastamonu Guidance and Research Center of the MoNe. He completed his Master's thesis in the Institute of Educational Sciences of Karabuk University Institute of Health Sciences.

Arzu ÖZYÜREK, Karabük Üniversitesi Sağlık Bilimleri Fakültesi Çocuk Gelişimi Bölümünde öğretim üyesi olarak görev yapmaktadır. Çalışma alanları arasında çocuk gelişimi ve eğitimi, aile eğitimi, eğitimde farklı yaklaşımlar yer almaktadır. 
Arzu Özyürek is a professor in Karabuk University Faculty of Health Sciences Department of Child Development. Her main research areas include child development and education, family education and different approaches to education.

Ek: ABTÖ A-Formu Türk İşaret Diline Çevrilmiş Versiyonunun Son Hali (Örnek Maddeler)

\begin{tabular}{|c|c|c|c|}
\hline $\begin{array}{l}\text { Video } \\
\text { Konu } \\
\end{array}$ & Özgün Madde & $\begin{array}{c}\text { TID Transkripsiyonunun } \\
\text { Türkçe Versiyonu }\end{array}$ & $\begin{array}{c}\text { Ölçeğin TíD Transkripsiyon } \\
\text { Versiyonu } \\
\end{array}$ \\
\hline $\begin{array}{l}2 . \\
\text { Madde }\end{array}$ & $\begin{array}{l}\text { Çocuğum için } \\
\text { koyduğum bir } \\
\text { kuralı asla } \\
\text { değiştirmem. }\end{array}$ & $\begin{array}{l}\text { Zaman yönetimi, sosyal } \\
\text { yaşant1, okul ya da } \\
\text { herhangi bir konuda } \\
\text { çocuğum için koyduğum } \\
\text { kuralları kendisi zamanla } \\
\text { değiştirmeye çalışsa bile } \\
\text { ben asla değiştirmem. }\end{array}$ & $\begin{array}{l}\text { O (BEN) ÇOCUK KURAL SAAT } \\
\text { (VAKİT) GEZMEK OKUL (GİBI) } \\
\text { HERTÜRLÜ KOYMAK BITMEK O } \\
\text { (ÇOCUK) ZAMAN (IÇîN) } \\
\text { DEĞİSMEK BEN ASLA } \\
\text { DEĞIŞMEK DEĞILIL HEP AYNI }\end{array}$ \\
\hline $\begin{array}{l}17 . \\
\text { Madde }\end{array}$ & $\begin{array}{l}\text { Çocuğum için, } \\
\text { her zaman } \\
\text { uyması gereken } \\
\text { kurallar } \\
\text { koymam. }\end{array}$ & $\begin{array}{l}\text { Çocuğumdan kendisi için } \\
\text { koyduğum kurallara } \\
\text { sürekli uymasını değil ara } \\
\text { sıra uymasını beklerim. }\end{array}$ & $\begin{array}{l}\text { BEN ÇOCUK O KURAL KOYMAK } \\
\text { KOYMAK HAZIR BITTMEK } \\
\text { MECBUR BU KURAL KURAL } \\
\text { HADİ HADİ (UY UY/YAP YAP) } \\
\text { (BEN) HER GÜN DEĞİL BAZEN } \\
\text { YAPMAK(BEKLEMEK) }\end{array}$ \\
\hline $\begin{array}{l}37 . \\
\text { Madde }\end{array}$ & $\begin{array}{l}\text { Çocuğuma } \\
\text { hiçbir zaman } \\
\text { şiddet } \\
\text { uygulamam. }\end{array}$ & $\begin{array}{l}\text { Yaramazlık yaptı̆̆ında ve } \\
\text { hatalı davrandığında bile } \\
\text { ben çocuğumu asla } \\
\text { dövmem ve ona şiddet } \\
\text { uygulamam. }\end{array}$ & $\begin{array}{l}\text { BEN ÇOCUK O YARAMAZLIK } \\
\text { YARAMAZLIK HATA HATA } \\
\text { YAPMAK BEN O(NA) EZIYYT } \\
\text { DÖVMEK DÖVMEK HIÇ }\end{array}$ \\
\hline
\end{tabular}

Ek: ABTÖ A-Formu TID Versiyonu Online Form Sayfa Örnekleri

ANNE BABALARIN ÇOCUK YETIŞTIRME TUTUMLARI ÖLÇEĞi (ABTÖ)-A FORMU'NUN TÜRK IŞARET DILI'NE UYARLAMA ÇALIŞMASI

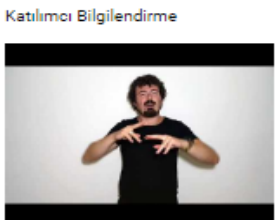

SAĞIR ANNE BABALARIMIZ:

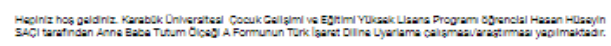

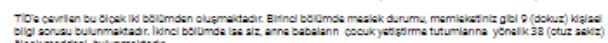

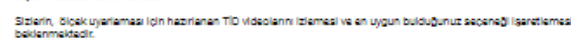

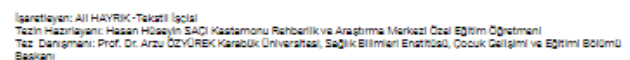

KIŞiSEL BILLGILER BÖLÜMÜ

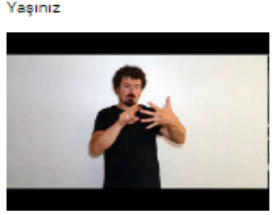

Kạ̣ yą̧ındasınız? Seçenekleri inceleyip, size uygun olanı įaretleyiniz.

25yeswats (24,23,22,21,20,10,18)

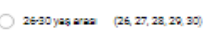

3195y yaseres (31, 32, 31, 34435)

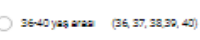

$4145) 4620202 \quad(41,42,43,44,45)$

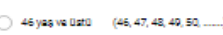




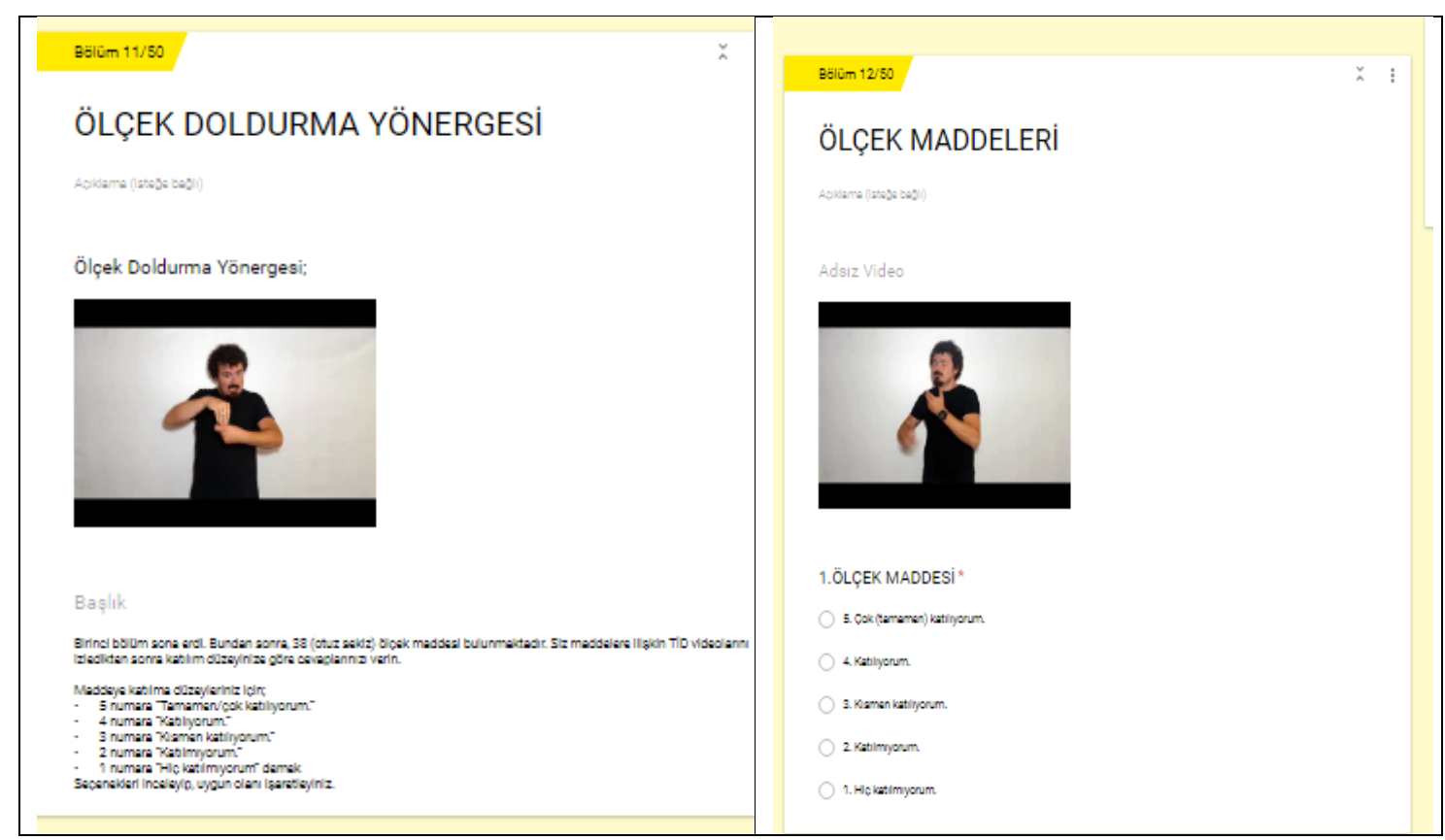

Not: Ölçeğin Google Form uygulaması ile oluşturulmuş TỉD versiyonuna aşağıdaki linkten ulaşılabilmektedir.

https://docs.google.com/forms/d/1zsTN7pY6YX3GyUVe9YgK2LDsyEMVi4wp9U $\underline{14 \mathrm{i} 2 \mathrm{Nx} 8 \mathrm{Ig} / \text { viewform?chromeless }=1 \& \text { edit_requested=true }}$ 